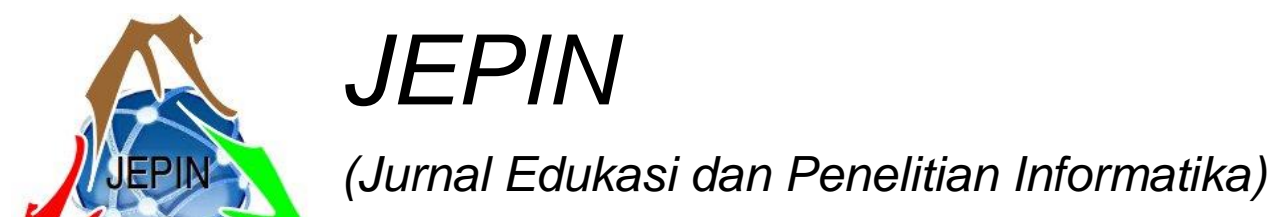

\title{
Sistem Pendeteksi Masker pada Pengemudi Kendaraan Menggunakan Kecerdasan Artifisial
}

\author{
Alief Wikarta ${ }^{\# 1}$, M Khoirul Effendi ${ }^{\# 2}$, Agus Sigit Pramono ${ }^{\# 3}$

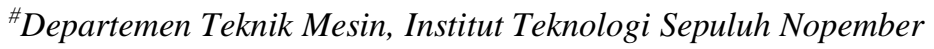 \\ Kampus ITS, Keputih, Surabaya 60111 \\ ${ }^{1}$ wikarta@me.its.ac.id \\ 2khoirul_effendi@me.its.ac.id \\ ${ }^{3}$ pramonodme.its.ac.id
}

\begin{abstract}
Abstrak- Deteksi penggunaan masker pada pengemudi kendaraan termasuk tugas klasifikasi yang dapat diselesaikan secara otomatis oleh kecerdasaan artifisial. Untuk implementasi pada perangkat mobile, arsitektur neural network MobileNetV2 dipilih dengan pertimbangan akurasi yang baik. Penambahan teknik data augmentation dan pemilihan optimizer ADAM semakin meningkatkan akurasi klasifikasi dari MobileNetV2. Proses deteksi dilakukan pada 13 foto pengemudi dengan masker dan 13 pengemudi tanpa masker. Untuk pengemudi tanpa masker, sistem pendeteksi berhasil $100 \%$, meskipun ada salah satu kondisi saat pengemudi memakai masker di dagu, tingkat akurasi hanya sebesar $65,59 \%$. Sedangkan untuk pengemudi tanpa masker, ada 1 foto yang salah, disebabkan oleh warna gelap yang digunakan sebagai masker, sehingga sistem pendeteksi mengklasifikasikan sebagai pengemudi tanpa masker dengan tingkat akurasi hingga 97,76\%. Hasil analisis lebih dalam menunjukkan bahwa aksesoris seperti jilbab dan kacamata mempengaruhi tingkat akurasi yang dihasilkan oleh sistem pendeteksi. Sementara itu, tingkat akurasi juga lebih dipengaruhi oleh warna dari masker yang dipakai ketimbang pemilihan masker medis ataupun masker kain.
\end{abstract}

Kata kunci - Pendeteksi Masker, Kecerdasan Artifisial, Pengemudi Kendaraan, Tingkat Akurasi.

\section{Pendahuluan}

Pengemudi kendaraan taksi yang konvensional maupun online menerima dampak pandemi Covid-19 seperti halnya pekerja sektor lain. Untuk mencegah penyebaran virus corona, pemakaian masker menjadi salah satu protokol kesehatan yang harus dipenuhi [1], [2]. Pendeteksian penggunaan masker oleh pengemudi kendaraan dapat dilakukan secara manual maupun otomatis. Deteksi secara manual seringkali kurang efisien karena membutuhkan pengamat dalam jumlah yang banyak. Sementara pendeteksian secara otomatis membutuhkan program yang akurat supaya lebih memaksimalkan efektifitas dan efisiensi yang sudah dimiliki.
Semenjak mulai pandemi tahun 2020 hingga sekarang, telah ada beberapa publikasi deteksi masker, yang dilakukan oleh peneliti di dalam negeri. Dalam penelitiannya, Lambacing dan Ferdiansyah (2020) menggunakan raspberry pi sebagai pendeteksi masker dengan notifikasi telegram berbasis Internet of Things [3] Sementara Anarki, dkk (2021) menerapkan metode haar cascade untuk aplikasi deteksi masker [4]. Metode deteksi lain secara otomatis adalah dengan menerapakan neural network dan deep learning. Putri, dkk (2021) menggunakan metode Convolutional Neural Networks $(C N N)$ dengan dataset yang diambil bervariasi dari berbagai negara seperti Asia, Eropa dan Amerika [5]. Arwindo, dkk (2020) menggunakan arsitektur YOLOv3, untuk mewujudkan deteksi masker yang robust dan presisi [6]. Sedangkan Harfi, dkk (2021) menerapkan deep learning untuk deteksi penggunaan masker pada berbagai jenis masker, beberapa kondisi pencahayaan, serta kondisi diam maupun berjalan [7].

Selain publikasi yang dilakukan oleh peneliti dalam negeri, pendeteksi masker secara otomatis juga dilakukan oleh peneliti dari luar negeri. Yadav (2020), menggunakan computer vision yang efisien berbasiskan algoritma deep learning untuk mendeteksi pemakaian masker dan jaga jarak [8]. Inamdar (2020) membuat tiga klasifikasi berupa memakai masker, menggunakan masker tapi tidak tepat, dan tanpa masker berdasarkan pada metode deep learning [9]. Kemudian Chowdary (2020) mengaplikasikan model transfer learning dari Inception V3 dengan teknik data augmentation untuk mendeteksi penggunaan masker [10]. Loey (2021) memakai model hybrid antara deep learning dengan machine learning untuk mendeteksi masker [11]. Jiang (2020) membuat deteksi penggunaan masker menggunakan MobileNet untuk perangkat mobile dengan akurasi yang bagus [12].

Penggunaan metode deep learning terutama dengan arsitektur MobileNet untuk perangkat mobile menunjukkan akurasi yang baik. Untuk itu perlu ada studi yang mendalami tentang pengaruh dari bermacam parameter dari MobileNet terhadap akurasi dari model 
deep learning. Hasil studi tersebut akan membantu terwujudnya pendeteksi masker yang akurat menggunakan perangkat mobile dengan spesifikasi terbatas. Studi oleh peneliti telah dilakukan untuk menganalisa pengaruh dari parameter ukuran data testing dan augmentation [13] serta bermacam optimizer [14] terhadap akurasi pendeteksi masker yang menggunakan arsitektur MobileNet maupun MobileNetV2. Hasil studi menunjukkan bahwa optimizer tipe ADAM pada arsitektur MobileNetV2 dengan menggunakan ukuran data augmentation menghasilkan akurasi yang baik saat proses training maupun testing.

Oleh karena itu pada artikel ini akan melanjutkan penelitian dengan melakukan pengujian pendeteksi masker untuk beberapa kondisi pengemudi kendaraan, yakni memakai masker kain, masker medis, pengemudi berjilbab, maupun memakai kacamata.

\section{Metode}

Proses pendeteksian masker menggunakan kecerdasan artifisial ditunjukkan pada Gambar 1. Dimana ada 2 proses utama yang perlu dilakukan. Pertama, adalah proses training dan testing dari arsitektur MobileNetV2 dengan optimizer ADAM menggunakan teknik data augmentation pada dataset hingga didapatkan sebuah model pendeteksi. Proses kedua adalah mendeteksi region of interest (ROI) yaitu posisi wajah dari pengendara kendaraan. Kemudian pada ROI tersebut dijalankan model pendeteksi dari deep learning yang telah ditraining sehingga didapatkan hasil pendeteksian berupa wajah pengendara menggunakan masker atau tidak menggunakan masker.

Kecerdasan artifisial, khususnya deep learning, telah banyak digunakan untuk berbagai macam aplikasi computer vision, diantaranya untuk autonomous car maupun smart CCTV. Keunggulan dari deep learning adalah kemampuannya untuk mendeteksi object dengan akurat lewat convolutional neural network (CNN). Namun demikian, arsitektur CNN biasanya membutuhkan komputer dengan spesifikasi Graphical Processor Unit $(G P U)$ yang tinggi. Padahal dalam beberapa aplikasi computer vision memakai pendekatan edge computing dengan spesifikasi GPU yang terbatas. Untuk itu, peneliti di Google mengembangkan arsitektur yang disebut MobileNet, yang ramah untuk edge computing serta aplikasi mobile, sesuai dengan namanya [15]. Perbedaan utama antara MobileNet dengan arsitektur CNN pada umumnya terletak pada penggunaan lapisan atau layer konvolusi dengan ketebalan filter yang sesuai dengan ketebalan dari input image [16].

Pada tahun 2017, Google meluncurkan versi terbaru yang disebut dengan MobileNetV2 dimana ada 2 tambahan fitur, yaitu linear bottleneck dan shortcut connection antar bottleneck [17]. Gambar 2 menunjukkan arsitektur dari MobileNetV2, dimana dengan kedua fitur baru tersebut, proses training pada neural network dapat berjalan dengan lebih cepat dan menghasilkan akurasi yang lebih baik. Dengan mempertimbangan kelebihan tersebut, maka pendeteksian masker pada pengemudi kendaraan menggunakan arsitektur MobileNetV2.

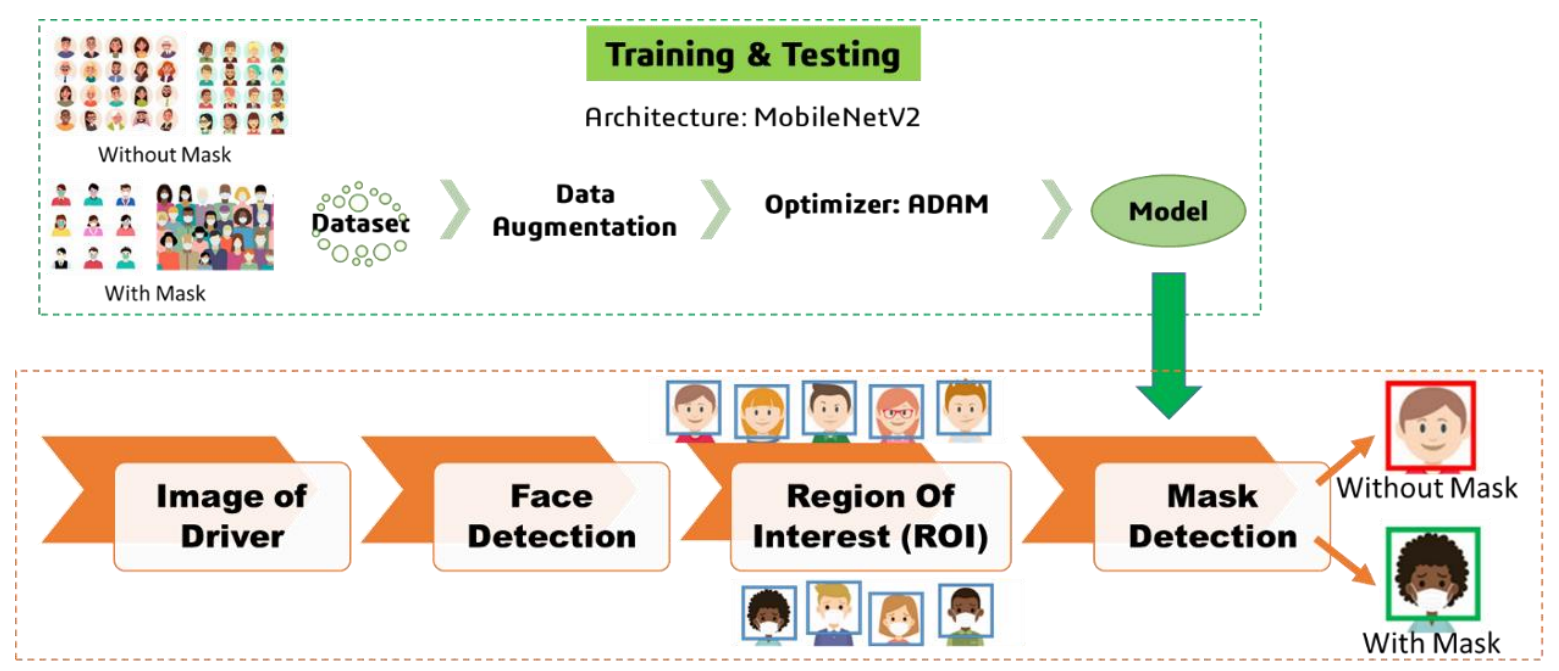

Gambar 1. Proses pendeteksian masker menggunakan kecerdasan artifisial

Umumnya arsitektur pada deep learning membutuhkan jumlah data yang sangat banyak dibandingkan dengan algoritma kecerdasan artifisial yang lain. Sementara itu, jumlah dataset yang digunakan untuk pendeteksian masker masih terbatas, sehingga masih belum cukup guna mendapatkan akurasi yang baik. Salah satu teknik untuk memperbanyak jumlah dataset tanpa kehilangan esensi dari data tersebut adalah data augmentation [18]. Pada studi kasus sebuah gambar, data augmentation yang dilakukan berupa rotate, flip, crop, zoom, shear, ataupun shifting.

Untuk menentukan kondisi optimum dari arsitektur MobileNetV2, ada beberapa pilihan optimizer yang dapat digunakan, diantaranya Stochastic Gradient Descent $(S G D)$, RMSProp, dan ADAM. Kelebihan dari optimizer ADAM adalah kemampuannya untuk mengkombinasikan fitur terbaik dari SGD dan RMSProp sehingga dapat bekerja dengan baik pada berbagai permasalahan [19], 
[20]. Untuk implementasi pendeteksi masker pada pengemudi kendaraan, optimizer ADAM menghasilkan akurasi tertinggi sebesar 0,9654, lebih baik ketimbang SGD maupun RMSProp dengan akurasi 0,7577 dan 0,9577 [14].

\begin{tabular}{c|c|c|c|c|c}
\hline Input & Operator & $t$ & $c$ & $n$ & $s$ \\
\hline $224^{2} \times 3$ & conv2d & - & 32 & 1 & 2 \\
$112^{2} \times 32$ & bottleneck & 1 & 16 & 1 & 1 \\
$112^{2} \times 16$ & bottleneck & 6 & 24 & 2 & 2 \\
$56^{2} \times 24$ & bottleneck & 6 & 32 & 3 & 2 \\
$28^{2} \times 32$ & bottleneck & 6 & 64 & 4 & 2 \\
$14^{2} \times 64$ & bottleneck & 6 & 96 & 3 & 1 \\
$14^{2} \times 96$ & bottleneck & 6 & 160 & 3 & 2 \\
$7^{2} \times 160$ & bottleneck & 6 & 320 & 1 & 1 \\
$7^{2} \times 320$ & conv2d 1x1 & - & 1280 & 1 & 1 \\
$7^{2} \times 1280$ & avgpool 7x7 & - & - & 1 & - \\
$1 \times 1 \times 1280$ & conv2d 1x1 & - & $\mathrm{k}$ & - & \\
\hline
\end{tabular}

Gambar 2. Arsitektur dari MobileNetV2 [21]

\section{HASIL DAN PEMBAHASAN}

Sistem kerja dari pendeteksi adalah mengidentifikasi area wajah dari pengemudi, yang selanjutnya menerapkan model deep learning untuk mendeteksi pakai masker atau tidak pakai masker. Gambar 3 adalah hasil dari sistem pendeteksi masker menggunakan kecerdasan artifisial. Dimana pada gambar tersebut tampak kotak di area wajah dari pengemudi dengan angka persentase tingkat akurasi. Untuk kotak warna merah menandakan bahwa sistem pendeteksi mengklasifikasikan wajah tanpa memakai masker. Sementara untuk kotak warna hijau menunjukkan hasil klasifikasi berupa wajah yang pakai masker.

Pada artikel ini, proses deteksi masker dilakukan pada foto-foto pengemudi kendaraan yang didapatkan dari penelusuran di google image. Foto-foto pengemudi tersebut digunakan sebagai input gambar yang akan dideteksi oleh kecerdasan artifisial. Hasil deteksi ditampilkan berupa kotak warna yang disertai tingkat akurasi untuk tiap input gambar.
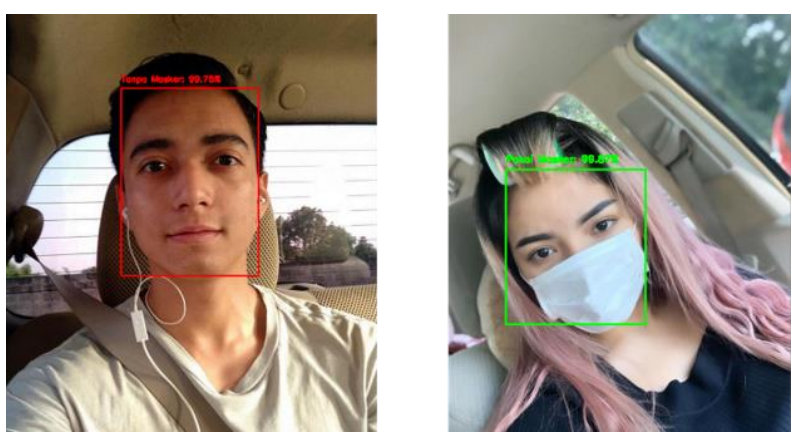

Gambar 3. Hasil deteksi pada pengemudi kendaraan

Pembahasan lebih mendalam tentang hasil deteksi tersebut disajikan pada Tabel 1 dan Tabel 2 untuk memudahkan analisis. Tabel 1 menunjukkan tingkat akurasi untuk bermacam foto pengemudi yang tanpa masker. Sedangkan Tabel 2 menunjukkan tingkat akurasi untuk bermacam foto pengemudi dengan masker maupun tidak memakai masker.

Pada Tabel 1, seluruh foto pengemudi tanpa masker dapat diklasifikasikan dengan akurat, dengan kata lain tidak ada kesalahan pada hasil deteksi. Meskipun demikian, pengamatan lebih dalam terhadap tingkat akurasi menunjukkan beberapa hasil yang menarik untuk didiskusikan. Untuk pengemudi nomer 11 yang memakai masker di dagu, tingkat akurasi hanya sebesar $65,59 \%$. Ini berarti sistem pendeteksi dapat mengklasifikasikan dengan benar namun cukup tersamarkan oleh adanya masker di daerah ragu, terutama saat identifikasi bagian wajah dari pengemudi.
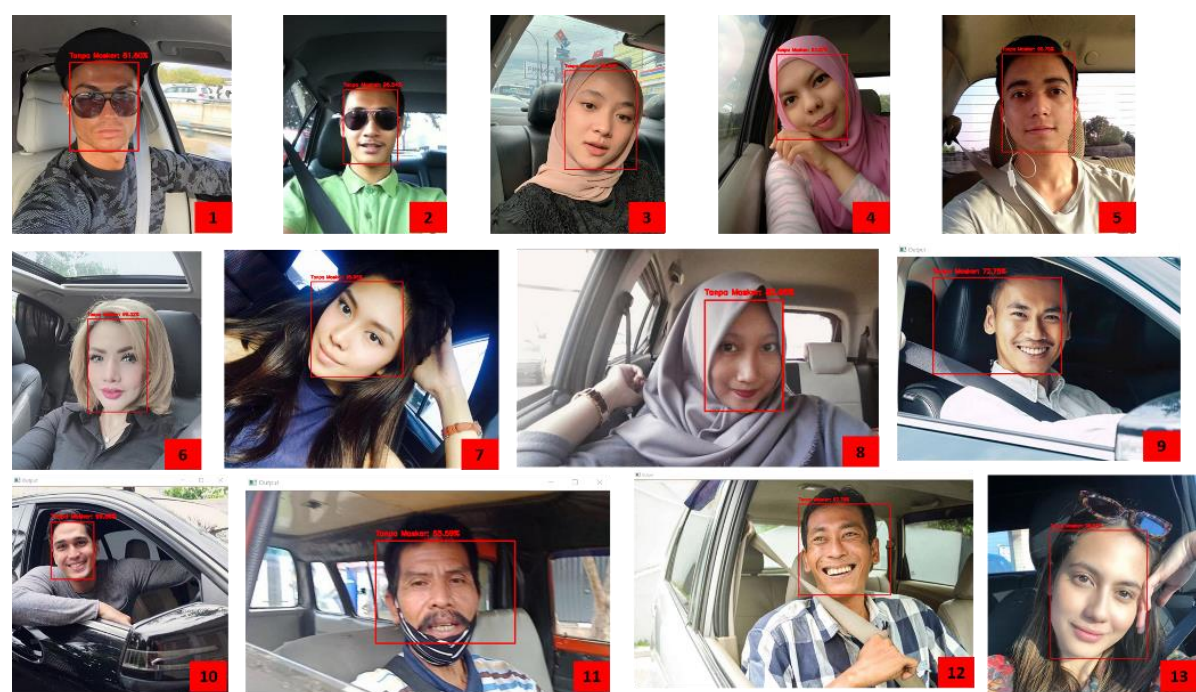

Gambar 4. Hasil deteksi pada 13 pengemudi yang tidak memakai masker 

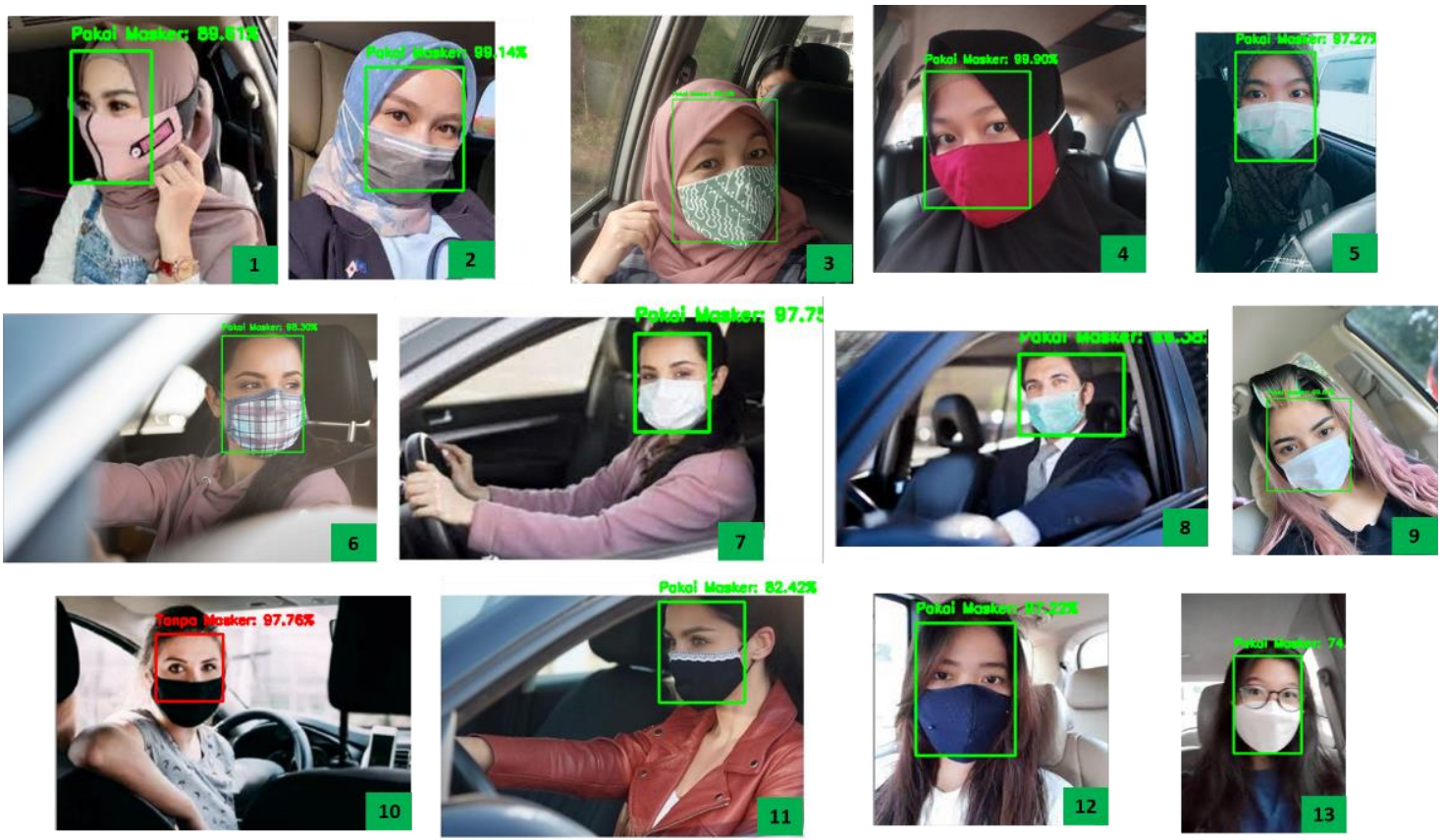

Gambar 5. Hasil deteksi pada 13 pengemudi yang memakai masker

Hal menarik lainnya adalah 2 dari 3 foto pengemudi berjilbab (nomer 3 dan 8) memiliki tingkat akurasi $68,35 \%$ dan $82,66 \%$ seperti terlihat pada Gambar 4. Tingkat akurasi itu tidak sebaik klasifikasi pada perempuan tanpa jilbab yang berada di atas $95 \%$. Ini menunjukkan bahwa penentuan Region of Intereset (ROI) pada bagian wajah dari pengemudi akan lebih mudah dan akurat jikaa tidak ada aksesoris. Hal yang serupa juga ditunjukkan pada foto pengemudi nomer 1, dimana hanya memiliki akurasi $81,6 \%$ karena pengemudi memakai kacamata.

TABEL I

TINGKat AKURASI PADA DETEKSI PENGEMUdi TANPA MASKER

\begin{tabular}{|c|c|c|c|l|}
\hline No & Foto Pengemudi & Akurasi (\%) & Hasil Deteksi & \multicolumn{1}{|c|}{ Keterangan } \\
\hline 1 & tanpa masker & 81,6 & tanpa masker & kacamata \\
\hline 2 & tanpa masker & 95,54 & tanpa masker & kacamata \\
\hline 3 & tanpa masker & 68,35 & tanpa masker & jilbab \\
\hline 4 & tanpa masker & 93,67 & tanpa masker & jilbab \\
\hline 5 & tanpa masker & 99,75 & tanpa masker & laki-laki \\
\hline 6 & tanpa masker & 99,32 & tanpa masker & perempuan \\
\hline 7 & tanpa masker & 95,96 & tanpa masker & perempuan \\
\hline 8 & tanpa masker & 82,66 & tanpa masker & jilbab \\
\hline 9 & tanpa masker & 72,75 & tanpa masker & laki-laki \\
\hline 10 & tanpa masker & 99,88 & tanpa masker & laki-laki \\
\hline 11 & tanpa masker & 65,59 & tanpa masker & masker di dagu \\
\hline 12 & tanpa masker & 97,78 & tanpa masker & laki-laki \\
\hline 13 & tanpa masker & 98,83 & tanpa masker & perempuan \\
\hline
\end{tabular}

Untuk deteksi pada foto pengemudi yang memakai masker, penggunaan masker medis ataupun masker kain bukan menjadi faktor utama dalam menentukan tingkat akurasi. Penggunaan aksesoris seperti kacamata dan jilbab lebih memberikan pengaruh pada tingkat akurasi deteksi pengemudi yang memakai masker. Pada Tabel 2 menunjukkan bahwa pengemudi nomer 1 dan 3 yang berjilbab dan memiliki tingkat akurasi di kisaran $89 \%$. Kemudian pada pengemudi nomer 13 yang berkacamata memiliki tingkat akurasi sebesar $74 \%$ seperti ditunjukkan
Gambar 5. Hal ini sesuai dengan pembahasan pada sistem deteksi pengemudi tanpa masker, dimana untuk pengemudi dengan memakai jilbab dan kacamata akan mampu terklasifikasikan dengan baik namun menghasilkan tingkat akurasi yang kurang.

TABEL II

TingKat AKURAsi PADA DETEKSI PENGEMUdi YANG MEMAKaI MASKER

\begin{tabular}{|c|c|c|c|l|}
\hline No & Foto Pengemudi & Akurasi (\%) & Hasil Deteksi & \multicolumn{1}{|c|}{ Keterangan } \\
\hline 1 & pakai masker & 89,61 & pakai masker & masker kain, jilbab \\
\hline 2 & pakai masker & 98 & pakai masker & masker medis, jilbab \\
\hline 3 & pakai masker & 89,92 & pakai masker & masker kain, jilbab \\
\hline 4 & pakai masker & 99,9 & pakai masker & masker kain, jilbab \\
\hline 5 & pakai masker & 97,27 & pakai masker & masker medis, jilbab \\
\hline 6 & pakai masker & 98,3 & pakai masker & masker kain \\
\hline 7 & pakai masker & 97,75 & pakai masker & masker medis \\
\hline 8 & pakai masker & 99,38 & pakai masker & masker medis \\
\hline 9 & pakai masker & 99,57 & pakai masker & masker medis \\
\hline 10 & pakai masker & 97,76 & tanpa masker & masker kain warna gelap \\
\hline 11 & pakai masker & 82,42 & pakai masker & masker kain warna gelap \\
\hline 12 & pakai masker & 97,22 & pakai masker & masker kain \\
\hline 13 & pakai masker & 74 & pakai masker & masker medis, kacamata \\
\hline
\end{tabular}

Ada satu pengemudi nomer 10 yang tidak berhasil diklasifikasikan dengan baik oleh sistem pendeteksi. Pengemudi tersebut harusnya memakai masker, namun dideteksi tanpa masker dengan tingkat akurasi hingga 97\%. Penyebab dari kegagalan deteksi ini lebih disebabkan oleh warna gelap yang digunakan sebagai masker. Dimana hal tersebut menyulitkan sistem pendeteksi untuk menentukan Region of Interest (ROI) sekaligus mendeteksi pemakaian masker. Hal ini diperkuat dengan tingkat akurasi yang kurang baik pada pengemudi nomer 11, yang memakai masker kain warna gelap. Meskipun hasil klasifikasi berhasil dengan bagus, namun tingkat akurasinya hanya $82,42 \%$. Ini berarti sistem pendeteksi berbasiskan kecerdasaran artifisial 
mudah tersamarkan oleh warna masker dalam mendeteksi penggunaan masker oleh pengemudi kendaraan.

\section{KESIMPULAN}

Pada artikel ini telah disajikan hasil deteksi pemakaian masker pada pengemudi kendaraan dengan menggunakan kecerdasan artifisial. Untuk pengemudi tanpa masker, sistem pendeteksi mampu mengklasifikasikan dengan tepat 13 dari 13 foto pengemudi tanpa masker, meskipun ada salah satu kondisi saat pengemudi memakai masker di dagu, tingkat akurasi hanya sebesar $65,59 \%$. Sementara untuk pengemudi dengan masker, sistem pendeteksi gagal mengklasifikasikan dengan benar 1 dari 13 foto pengemudi kendaraan dengan masker. Penyebab dari kegagalan deteksi ini lebih disebabkan oleh warna gelap yang digunakan sebagai masker, sehingga sistem pendeteksi malah mengklasifikasikan sebagai pengemudi tanpa masker dengan tingkat akurasi hingga 97,76\%. Foto pengemudi dengan memakai aksesoris seperti jilbab dan kacamata mempengaruhi tingkat akurasi yang dihasilkan oleh sistem pendeteksi. Sedangkan untuk pengemudi dengan masker, warna dari masker yang dipakai lebih berpengaruh pada tingkat akurasi, ketimbang pemilihan masker medis ataupun masker kain.

\section{UCAPAN TERIMA KASIH / ACKNOWLEDGMENT}

Artikel ini merupakan bagian dari hibah penelitian dana ITS (Departemen) dengan nomer kontrak: 1697/PKS/ITS/2020.

\section{REFERENSI}

[1] T. Greenhalgh, M. B. Schmid, T. Czypionka, D. Bassler, and L. Gruer, "Face masks for the public during the covid-19 crisis," BMJ, vol. 369, Apr. 2020, doi: 10.1136/bmj.m1435.

[2] [2] V. C.-C. Cheng et al., "The role of community-wide wearing of face mask for control of coronavirus disease 2019 (COVID-19) epidemic due to SARS-CoV-2," Journal of Infection, Apr. 2020 doi: 10.1016/j.jinf.2020.04.024

[3] M. M. Lambacing and F. Ferdiansyah, "RANCANG BANGUN NEW NORMAL COVID-19 MASKER DETEKTOR DENGAN NOTIFIKASI TELEGRAM BERBASIS INTERNET OF THINGS," Dinamik, vol. 25, no. 2, Art. no. 2, Jul. 2020, doi: 10.35315/dinamik.v25i2.8070.

[4] G. A. Anarki, K. Auliasari, and M. Orisa, "PENERAPAN METODE HAAR CASCADE PADA APLIKASI DETEKSI MASKER,” JATI (Jurnal Mahasiswa Teknik Informatika), vol. 5, no. 1, Art. no. 1, Feb. 2021, doi: 10.36040/jati.v5i1.3214.

[5] T. S. N. P. Putri, M. A. Fikih, and N. Setyawan, "FACE MASK DETECTION COVID-19 USING CONVOLUTIONAL NEURAL NETWORK (CNN)," Prosiding SENTRA (Seminar Teknologi dan Rekayasa), vol. 0, no. 6, Art. no. 6, Jan. 2021, doi: 10.22219/sentra.v0i6.3801

[6] D. G. Arwindo, E. Y. Puspaningrum, and Y. V. Via, "Identifikasi Penggunaan Masker Menggunakan Algoritma CNN YOLOv3 Tiny," Prosiding Seminar Nasional Informatika Bela Negara, vol. 1, pp. 153-159, 2020.

[7] M. A. R. I. Harfi and D. A. Prasetya, "Prototipe Pendeteksi Masker pada Ruangan Wajib Masker untuk Kendali Pintu Otomatis berbasis Deep Learning sebagai Pencegahan Penularan COVID-19," Dec. 2020, Accessed: Mar. 06, 2021. [Online]. Available: http://publikasiilmiah.ums.ac.id/handle/11617/12377

[8] S. Yadav, "Deep Learning based Safe Social Distancing and Face Mask Detection in Public Areas for COVID-19 Safety Guidelines Adherence," International Journal for Research in Applied
Science and Engineering Technology, vol. 8, no. 7, pp. 13681375, Jul. 2020, doi: 10.22214/ijraset.2020.30560.

[9] M. Inamdar and N. Mehendale, "Real-Time Face Mask Identification Using Facemasknet Deep Learning Network," Social Science Research Network, Rochester, NY, SSRN Scholarly Paper ID 3663305, Jul. 2020. doi: 10.2139/ssrn.3663305.

[10] G. J. Chowdary, N. S. Punn, S. K. Sonbhadra, and S. Agarwal, "Face Mask Detection using Transfer Learning of InceptionV3," Sep. 2020, Accessed: Oct. 20, 2020. [Online]. Available: https://arxiv.org/abs/2009.08369v1

[11] M. Loey, G. Manogaran, M. H. N. Taha, and N. E. M. Khalifa, “A hybrid deep transfer learning model with machine learning methods for face mask detection in the era of the COVID-19 pandemic," Measurement, vol. 167, p. 108288, Jan. 2021, doi: 10.1016/j.measurement.2020.108288.

[12] M. Jiang, X. Fan, and H. Yan, "RetinaMask: A Face Mask detector," arXiv:2005.03950 [cs], Jun. 2020, Accessed: Aug. 24, 2020. [Online]. Available: http://arxiv.org/abs/2005.03950

[13] A. Wikarta, I. B. Suryo, and M. K. Effendi, "Analisa Pengaruh Ukuran Testing Data dan Data Augmentation pada Tingkat Akurasi Deteksi Pemakaian Masker oleh Pengemudi Kendaraan menggunakan Deep Learning," SENTER, pp. 20-24, Jan. 2021.

[14] A. Wikarta, A. S. Pramono, and J. B. Ariatedja, "ANALISA BERMACAM OPTIMIZER PADA CONVOLUTIONAL NEURAL NETWORK UNTUK DETEKSI PEMAKAIAN MASKER PENGEMUDI KENDARAAN," Seminar Nasional Informatika (SEMNASIF), vol. 1, no. 1, Art. no. 1, Dec. 2020.

[15] A. G. Howard et al., "MobileNets: Efficient Convolutional Neural Networks for Mobile Vision Applications," arXiv:1704.04861 [cs], Apr. 2017, Accessed: May 21, 2021. [Online]. Available: http://arxiv.org/abs/1704.04861

[16] R. O. Ekoputris, "MobileNet: Deteksi Objek pada Platform Mobile," Medium, May 09, 2018 https://medium.com/nodeflux/mobilenet-deteksi-objek-padaplatform-mobile-bbbf3806e4b3 (accessed May 21, 2021).

[17] M. Sandler, A. Howard, M. Zhu, A. Zhmoginov, and L.-C. Chen, "MobileNetV2: Inverted Residuals and Linear Bottlenecks," arXiv:1801.04381 [cs], Mar. 2019, Accessed: May 21, 2021. [Online]. Available: http://arxiv.org/abs/1801.04381

[18] C. Shorten and T. M. Khoshgoftaar, "A survey on Image Data Augmentation for Deep Learning," Journal of Big Data, vol. 6, no. 1, p. 60, Jul. 2019, doi: 10.1186/s40537-019-0197-0.

[19] D. P. Kingma and J. Ba, "Adam: A Method for Stochastic Optimization,” Dec. 2014, Accessed: Nov. 23, 2020. [Online]. Available: https://arxiv.o rg/abs/1412.6980v9

[20] S. Ruder, "An overview of gradient descent optimization algorithms," Sep. 2016, Accessed: Nov. 23, 2020. [Online]. Available: https://arxiv.org/abs/1609.04747v2

[21] S.-H. Tsang, "Review: MobileNetV2 — Light Weight Mode (Image Classification)," Medium, Aug. 01, 2019. https://towardsdatascience.com/review-mobilenetv2-light-weightmodel-image-classification-8febb490e61c (accessed May 21, 2021). 